\title{
Mescaline facilitates retention of passive avoidance in rats*
}

\author{
JEFFREY KAHN \\ Swarthmore College, Swarthmore, Pennsylvania 19081 \\ DAVID A. GORELICK \\ Department of Pharmacology, Albert Einstein College of Medicine, Bronx, New York 10461 \\ and \\ WAGNER H. BRIDGER $\dagger$ \\ Department of Psychiatry, Albert Einstein College of Medicine, Bronx, New York 10461
}

\begin{abstract}
Male hooded rats were given one trial of step-through passive avoidance, then immediately injected with saline or mescaline (160 micromoles/ $\mathrm{kg}$ ip) and tested for retention $48 \mathrm{~h}$ later. Controls were given identical treatments, except that they did not. receive footshock during the training trial. Groups receiving footshock showed significant learning and retention, with the mescaline group showing significantly better retention than the saline group. The no-footshock groups showed no learning, with the mescaline group not differing from the saline. In a separate experiment, rats were given one trial of step-through passive avoidance, then injected with saline or mescaline (160 micromoles $/ \mathrm{kg} \mathrm{ip}) 72 \mathrm{~h}$ later and tested for retention $48 \mathrm{~h}$ after injection. The mescaline group did not differ from the saline, indicating that mescaline did not have a 48 -h proactive effect on performance in this task.
\end{abstract}

Hallucinogenic drugs, such as mescaline and LSD, profoundly disturb human psychological processes (Hoffer \& Osmond, 1967). Some investigators have reported a specific deficit in memory processes (Berlin, Guthrie, Weider, Goodell, \& Wolff, 1955; Jarvik, Abramson, \& Hirsch, 1955). However, since Ss were both trained and tested under the drug, interpretation of these experiments is difficult. In order to study the possible effect of mescaline on memory, we used the paradigm of one-trial passive avoidance, with posttraining injection of the drug. This paradigm avoids confounding acquisition and retention effects of the drug and has been widely used to study effects on memory in animals (McGaugh, 1968). However, only a limited amount of work in this area has been done with hallucinogens. Siegel and Jarvik (1971) reported no effect on memory when mice were given one passive avoidance trial, injected immediately with mescaline $(100 \mathrm{mg} / \mathrm{kg}$ ip) and retested $24 \mathrm{~h}$ later. Roberts, Darlington, and Bradley (1965) reported that LSD (20, 50 , or $100 \mathrm{micrograms} / \mathrm{kg}$ ip) caused a time-dependent disruption of memory when rats were given one passive avoidance trial, injected at some time afterwards, and retested $24 \mathrm{~h}$ later. Weissman (1967) found that rats given mescaline $(30 \mathrm{mg} / \mathrm{kg}$ ip), LSD $(1 \mathrm{mg} / \mathrm{kg}$ ip), or psilocybin $(20 \mathrm{mg} / \mathrm{kg}$ ip) $5 \mathrm{~min}$ after training showed no effect on memory when tested 24 or $72 \mathrm{~h}$ later.

In this paper we report the effect of mescaline (160 micromoles $/ \mathrm{kg}$ ip) given to rats immediately after training on performance of a one-trial step-through passive avoidance task, with testing done $48 \mathrm{~h}$ after

*This research was supported by Grant 5 KO5 MH04177 from NIMH and by Grant 5T5-GM1674 from NIH.

tRequests for reprints should be sent to Wagner $H$. Bridger, Department of Psychiatry, Albert Einstein College of Medicine, 1300 Morris Park A venue, Bronx, New York 10461. training. In order to detect a possible 48-h proactive effect of mescaline on performance, we also report the effect of mescaline ( 160 micromoles $/ \mathrm{kg}$ ip) given to rats $72 \mathrm{~h}$ after training on performance of the avoidance task, with testing done $48 \mathrm{~h}$ after injection $(120 \mathrm{~h}$ after training).

\section{METHOD}

Ss were 81 male hooded rats with an initial body weight of 171 to $320 \mathrm{~g}$. They were hou sed in individual wire mesh cages, in a windowless room, with a 9 a.m. to 9 p.m. light period. Food and water were available ad lib.

The apparatus consisted of two identical Lafayette No. 8500 modular testing units $(20.5 \times 30.5 \times 19.5 \mathrm{~cm})$ placed end-to-end and separated by a Lafayette automatic guillotine door (opening $9.0 \times 9.5 \mathrm{~cm})$. The startbox received diffuse overhead lighting from two $15-\mathrm{W}$ bulbs, while the goalbox was dark. Scrambled 1.6-mA shock was delivered to the goalbox for $2.0 \mathrm{sec}$ through a floor grid by a Grason-Stadler E1064GS shock generator.

\section{Experiment 1}

Ss were randomly divided among four treatment groups and run at $15-\mathrm{min}$ intervals between noon and 6 p.m. Groups were alternated or double alternated to preclude any possible order effects. On the training day, each animal was weighed and then placed in the startbox facing the center of the side wall. The weight of the rat on the startbox floor started a timer. When all four paws had crossed through the door, the timer was stopped, the door closed behind the rat, and, after a 0.5 -sec delay, shock was delivered. Shock was delayed until the door had completely closed in order to prevent the rat from returning to the startbox. After the 2.0-sec shock, the rat was removed from the goalbox and within $10 \mathrm{sec}$ given either saline (ip) or $160 \mathrm{micromoles} / \mathrm{kg}$ mescaline (ip, as $50 \mathrm{mg} / \mathrm{kg}$ mescaline sulfate dihydrate or $39.6 \mathrm{mg} / \mathrm{kg}$ mescaline hydrochloride). Injection volume was always $1.0 \mathrm{ml}$. For the two no-shock control groups, the identical procedure was followed, except that no shock was delivered to the floor grid.

Ss were tested $48 \mathrm{~h}$ later. On the test day, Ss were again weighed and then placed in the startbox. The crossing latency 
Table 1

\begin{tabular}{|c|c|c|c|}
\hline \multicolumn{4}{|c|}{ Crossing Latencies (Seconds) (Mean \pm SE) } \\
\hline \multicolumn{2}{|c|}{ Training Day } & \multicolumn{2}{|c|}{ Test Day } \\
\hline Saline & Mescaline & Saline & Mescaline \\
\hline \multicolumn{4}{|c|}{ Experiment 1: Shock } \\
\hline $\begin{array}{l}6.6 \pm 1.1 \\
(N=21)\end{array}$ & $\begin{array}{l}7.6 \pm 0.9 \\
(\mathrm{~N}=20)\end{array}$ & $128.8 \pm 48.4$ & $371.3 \pm 84.7$ \\
\hline \multicolumn{4}{|c|}{ Experiment 1: No Shock } \\
\hline $\begin{array}{l}6.3 \pm 0.7 \\
(\mathrm{~N}=10)\end{array}$ & $\begin{array}{l}6.5 \pm 1.3 \\
(\mathrm{~N}=10)\end{array}$ & $5.3 \pm 1.0$ & $4.0 \pm 0.6$ \\
\hline \multicolumn{4}{|c|}{ Experiment 2: Shock } \\
\hline $\begin{array}{l}8.0 \pm 2.3 \\
(\mathrm{~N}=10)\end{array}$ & $\begin{array}{l}7.0 \pm 1.1 \\
(N=10)\end{array}$ & $144.4 \pm 64.8$ & $172.7 \pm 71.7$ \\
\hline
\end{tabular}

was the period of time from the rat's being placed in the box until four paws were through the door. If the rat did not cross within $1000 \mathrm{sec}$, the trial was ended, and the rat was assigned a crossing latency of $1000 \mathrm{sec}$.

\section{Experiment 2}

The same procedure was used as that in Experiment 1, with the following exceptions. On the training day, all Ss received shock and a posttrial saline injection. Seventy-two hours after training, all Ss received a second injection of either saline or $160 \mathrm{micromoles} / \mathrm{kg}$ mescaline. Ss were tested $48 \mathrm{~h}$ after the second injection (120 h after training).

Data from both experiments were analyzed using a two-tailed Mann-Whitney U test.

\section{RESULTS}

The results are presented in Table 1. All groups showed comparable crossing latencies on the training day. Both groups that received shock showed significantly longer crossing latencies on the test day $(p<.001)$. The mescaline group showed significantly $(p<.05)$ longer crossing latencies than the saline group (Experiment 1). Control groups trained without shock showed neither significantly longer crossing latencies nor a significant difference between the mescaline and saline groups on the test day.

In Experiment 2 both groups showed significantly longer crossing latencies on the test day $(p<.001)$, but there was no significant difference between the mescaline and saline groups.

\section{DISCUSSION}

The results of Experiment 1 indicate that significant acquisition and retention of the passive avoidance task occurred in the groups receiving shock. The experiment also showed that mescaline given immediately posttraining facilitates performance on the test day. The lack of a mescaline effect in the no-shock groups suggests that mescaline is not a negative reinforcer and that there are no 48-h proactive effects of the drug on performance. The results of Experiment 2 also suggest the lack of a 48-h proactive mescaline effect. Therefore, the results of Experiment 1 can be explained in terms of facilitation of retention by mescaline.
This finding is inconsistent with past work cited above, which found no effect or a disruptive effect of hallucinogens on retention. Siegel and Jarvik (1971), using a step-through task similar to the one used in this study, reported no significant effect of mescaline on retention. However, it is not clear from their report on what data the statistical tests were performed. They report data for two independent samples of animals. The first sample had a median test latency of $313.0 \mathrm{sec}$ for the saline group and $290.0 \mathrm{sec}$ for the mescaline group. However, the second sample of animals had a saline latency of $365.0 \mathrm{sec}$ and a mescaline latency of $>600.0 \mathrm{sec}$. Taken alone, this second sample shows a strong trend toward facilitation of retention by mescaline. The difference between our finding and that of Siegel and Jarvik (1971) may also be attributed to several procedural differences in their experiment: use of mice, a higher mescaline dose $(100 \mathrm{mg} / \mathrm{kg})$, and a $24-\mathrm{h}$ training-test interval.

Weissman (1967), using a completely different task, found no effect of mescaline $(30 \mathrm{mg} / \mathrm{kg}$ ip, salt not specified) or other hallucinogens on retention. This lack of effect could be due to the lower dose of mescaline used or to the difference in task. Weissman trained thirsty rats to barpress for water, then gave them a single footshock immediately after the session. Thus, the active response tendency to be overcome was motivated by thirst, rather than by curiosity or aversion to light. In addition, the active response itself was barpressing rather than locomotion.

Roberts et al (1965), using a step-through task, found a disruptive effect of LSD $(20,50$, or $100 \mathrm{micrograms} / \mathrm{kg} \mathrm{ip)} \mathrm{on} \mathrm{retention,} \mathrm{with} \mathrm{the} \mathrm{effect}$ decreasing with increasing training-injection interval (30 $\mathrm{sec}$ to $15 \mathrm{~min})$. There was no dose-dependent variation of effect. The time-dependent effect is a classic finding in studies on retention and suggests that LSD is not exerting a proactive effect over the 24 -h training test interval. The opposite effect reported in the present study, i.e., mescaline facilitation of retention, could be due to different mechanisms of action of the two hallucinogens. One possibility is that mescaline, but not LSD, has some actions in common with amphetamine, a drug which has been shown to facilitate retention (McGaugh, 1968). This hypothesis is supported by the structural similarity between mescaline and amphetamine which LSD does not share. Although mescaline and LSD have many effects in common, mescaline also shares effects with amphetamine which LSD does not. For example, while mescaline and LSD inhibit the firing of certain midbrain raphe muclei neurons, mescaline, like amphetamine but unlike LSD, also increases the firing of other such neurons (Aghajanian, Foote, \& Sheard, 1970).

\section{REFERENCES}

Aghajanian, G. K., Foote, W. E., \& Sheard, M. H. Action of psychotogenic drugs on single midbrain raphe neurons. 
Journal of Pharmacology \& Experimental Therapeutics, 1970, 171, 178-187.

Berlin, L., Guthrie, T., Weider, A., Goodell, H., \& Wolff, H. G Studies in human cerebral function: The effects of mescaline and lysergic acid on cerebral processes pertinent to creative activity. Journal of Nervous \& Mental Disease, 1955, 122, 487-491.

Hoffer, A., \& Osmond, H. The hallucinogens. New York: Academic Press, 1967.

Jarvik, M. E., Abramson, H. A., \& Hirsch, M. W. Ly sergic acid diethylamide (LSD-25): VI. Effect upon recall and recognition of various stimuli. Journal of Psychology, 1955, 39, 443-454.

McGaugh, J. L. Drug facilitation of memory and learning. In D. $\mathrm{H}$. Efron (Ed,) Psychopharmacology: A review of progress 1957-1967. Washington, D.C: United States Government Printing Office, 1968.
Roberts, M. H. T., Darlington, D., \& Bradley, P. B. The effect of chlorpromazine and d-lysergic acid diethylamide on one-trial passive avoidance. In D. Bente and P. B. Bradley (Eds.), Neuro-psychopharmacology, Vol. 4. Proceedings of the 4th meeting collegium internationale neuro-psychopharmacologicum. New York: Elsevier, 1965.

Siegel, R. K., \& Jarvik, M. E. Evidence for state-dependent learning with mescaline in a passive avoidance task. Psychonomic Science, 1971, 25, 260-261.

Weissman, A. Drugs and retrograde amnesia. International Review of Neurobiology, 1967, 10, 167-198.

(Received for publication December 17, 1973 ; accepted January 1, 1974.) 